\title{
TITLE INDEX OF VOLUME 11
}

\section{EDITORIALS}

\section{UNITED NATIONS ACTIVITIES}

The 11th Session

- Extracts from Statements

- Debate on ED's Report

- Tolba Replies

- State of the Environment Report

- Topics for the 1984 Report

- Coordination Questions

- Sessional Committee I

- Plenary: The Last Two Days

UNEP

- Ozone Convention Discussed

- Pollution from Land-Based Sources

UNCTAD

- Tropical Timber Agreement on Course

UN/ECE

- Long-range Transboundary Air Pollution-Executive Body, First Session ((iregory Wetstone)

ECA

- A Decade of Involvement: The Challenge of Development Without Destruction of the African Environment

\section{OTHER INTERNATIONAL DEVELOPMENTS}

Les Forêts - Conclusions d'une Séminaire Spanish/Latin-American Environmental Law Antarctic Mineral Resources

Acid Rain: The International Perspective (Gregory Wetstone) Antarctic Mineral Resources (Harald Heimsoeth)

Sea Convention Discussed

No Agreement on ()il Slick

Confidentiality of Data and Chemical Control (Meinhard Schröder)

Bonn Convention in Force

Islamic Principles for the Conservation of the Natural Environment

A.C. Kiss Reçoit le Titre de Docteur Honoris Causa et Parle du

Patrimoine Commun de 'Humanite

Inuit Circumpolar Conference

OECD

- Chemicals Management

\section{REGIONAL ACTIVITIES}

EC

- Action to Combat Air Pollution

- Directive on Wild Birds

EEC

- Article 92 of the EEC Treaty and the Rhine Salt Question

- Ecology and Development

Legal Significance of Principles

Consultation Procedures

Law of the Sea

Regional Planning

Recording of Declarations in Council Minutes

\section{$1,55,87$ NATIONAL AFFAIRS}

Australia (New South Wales)

- Hazardous Chemical Wastes

106

Canada

- Information Access

- Environmental Board Proposed

- No Progress on Acid Rain

Germany, Federal Republic

- Urging for a Firm Clean-Air Policy Across National Borders (Hendrik Vygen)

- Environmental Modification Techniques 36

- Transboundary Air Pollution 107

Kenya

- Environmental Impact Assessment (Farouk Muslim)

Netherlands

58 - Aspects of Nuclear Energy Law (Barbara Kwiatkowski)

88 - New Constitution 105

\section{Spain}

91 - Environmental Offences

105

USA

- After Nuclear War

26

- Acid Rain Study

\section{INTERVIEWS}

Yuvraj Digvigay Sinh, Minister Responsible for the Environment in India

\section{SELECTED DOCUMENTS}

\section{UNEP}

Governing Council

- Periodicity and Duration of Council Sessions

- Impacts of Apartheid on the Environment

- Arms and the Environment

- Process of Preparation of the Environmental Perspective

- Decisions Approved by the Governing Council: Presented by Committee I

- Programme Matters

- Assistance to the South East Asia Cooperative Environment Programme

- Regional Programmes in Latin America and the Caribbean

- Decisions Approved by the Governing Council: Presented by Committee II

- Fund Appropriation

- Administrative Costs

- Additional Resources for Dealing with Serious Environmental Problems in Developing Countries

- Management of Environmental Fund Programme Support Costs

- Closing Statement of the President, Martin Holdgate

- Closing Statement of the Executive Director, Mostafa K. Tolba

- Measures to Control, Limit and Reduce the Use and Fmissions of Fully Halogenated Chlorofluoro-Carbons (CFCs) for the Protection of the ()zone Layer

- Protection of the Marine Environment against Pollution from Land-Based Sources (Draft (juidelines/Principles)

ECE

- Implementation of the Convention on Long-range Transboundary Air Pollution

EC

- Proposal for a Council Directive on the Combatting of Air Pollution from Industrial Plants
7

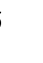

05

6

8

.


Antarctica

- Closing Statement of the 7th Summit of Non-aligned Nations at New Delhi

- Antarctic Mineral Resources

- Antarctic Mineral Resources Regime: Draft Articles

Germany, Federal Republic

- Convention on the Prohibition of Military or Any Other Hostile Use of Environmental Modification Techniques

- International Conference 1984 (Memorandum)
WEU

- Draft Recommendation on the Law of the Sea 81

54 - Law of the Sea (Resolution) 81

48 European Regional/Spatial Planning Charter 82

Islamic Principles for the Conservation of the Natural Environment 83

$\begin{array}{ll}\text { Inuit Circumpolar Conference: Resolutions } & 113\end{array}$

54

116

\section{AUTHOR INDEX OF VOLUME 11}

Heimsoeth, Harald, 59

Kwiatkowski, Barbara, 98

Muslim, Farouk, 69
Schröder, Meinhard, 64

Vygen, Hendrik, 34

Wetstone, Gregory, 26, 31 